\title{
Using Self-Regulated Strategy Development (SRSD) to Develop EFL Reading and Writing Skills
}

\author{
Hanan Ahmed El-Sayyed Sanad \\ Lecturer in the Department of English, Alghat College of Sciences and Humanities, Majmaah University
}

\begin{abstract}
The present paper aims at shedding light onself-regulation and self-regulated strategy development as an instructional approach designed to enhanceFL learners' strategic behavior, knowledge, and motivation, which in turn may affect their EFL writing skills. Different studies conducted in the field of EFL inside and outside Saudi Arabia to develop writing skills are surveyed. The paper depends on the descriptive method that covers the theoretical background of using the SRSD in developing EFL writing skills. Furthermore, the researcher depended on her experience in teaching reading and writing to Saudi college students and the results of their achievementtests. The papertried to investigate different definitions of self regulation and metacognition as its main aspect, beside different self-regulated strategies. The paper also discusseda cyclical model of self regulation from social-cognitive theory and research. Harris and Graham's SRSD model is coveredalso. This is followed by an analysis of teacher's role in using this approach.Conclusions are based on the conclusions obtained from review of literature and previous studies. These conclusionsmay be useful to be applied in the Saudi context generally and in Majmaah University specifically as they part of the EFL context.
\end{abstract}

\section{Introduction}

This paper studies one of the recent trends in teaching English as a foreign language, self- regulation, and its relationship with EFL writing and reading. Based on the fact that learning to write must go along with learning to read: one reinforces the other, research reveals that the division between reading and writing hinders the development of language learning in general and writing ability in specific (Ibrahim , 2006) .. Writing activities should be integrated with reading activities. As learners gain experience reading books and other printed matter, they increasingly try to spell words by using patterns they have seen in print. "Effective reading and writing skills are as important for effective communications speaking and listening skills" (Kondrat,2009) .

Based on the researcher's experience in teaching English for college students in Saudi Arabia, she observed that students suffer a problem in reading comprehension skills. They lack the fundamental skills of reading on its three levels; the literal, the interpretive and the critical or the evaluative one. Also, this lack of fundamental reading skills affects students' skills in writing . That's because mastery of the three levels of reading skills enables students to differentiate between main and sub-ideas in the text . Besides, they help students infer type of the text and purpose of the writer. These skills are basic for writing as well. At least, students lack the ability to get the reading texts as models for writing paragraphs or compositions. So, reading is an excellent predictor of writing competence (Mango , 2008).

The researcher's observations and conclusions are supported by many researchers and research results as shown in the theoretical background and review of literature part.

\section{Problem of the study}

In spite of the importance of reading and writing skills, they still form a challenge for EFL Saudi students .Great number of students struggle to master them . The problem of the present study is represented in the weakness in writing and reading skills among EFL Saudi college students. Thus the present study tries to find an effective approach or method that help develop both skills. The suggested strategy is called Self- Regulated Strategy Development ( SRSD) based on self- regulated learning .

\section{Significanceof the study}

The present study sheds light on an important trend in the field of EFL instruction that has not received attention in spite of being effective, self -regulated learning.

The present study uses SRSD to develop reading comprehension which consequently affects and facilitates the development of writing skills. Thus, solving the problem that most EFL students in Saudi colleges face when studying basic EFL skills in the lower levels of the college. 


\section{Question of the study:}

The present study tries to answer the following question:

Does self- regulation strategy development affect EFL writing and reading skills?

\section{Method of the study:}

A descriptive method is used to uncover the strong relationship between reading and writing skills reviewing literature and previous studies concerning an important approach that is used to develop both reading and writing separately.

\section{EFL Writing:}

\section{Theoretical Literature and Review of Studies}

Writing is one of the primary cornerstones on which content learning is built (Adams, Treiman and Pressely, 2000). Essa (2009) stated that writing posses challenges for many students . Students use writing to share and gather information (Graham and Harris ,2005). It provides useful tool for exploring, organizing and verifying ideas. Despite the importance of writing, great number of students struggle to master it (Lane et al. 2008). It also provides powerful mechanism for communication, self -expression and self- reflection (Graham, 2006 b). While composing, a writer must manage complex problem solving

writing processes that include planning, considering the audience's needs and perspectives, generating organized content, and revising for form and ideas(Saddler, 2006).

Writing is a goal-directed action; the writer directs the process from start to finish, utilizing his or her personal observations, judgments, and reactions as a guide (Graham \& Harris, 1994). Success at writing requires a substantial amount of self-regulation and effort (Graham, Harris, \& Troia, 1998).

Sinclaire (2004) reported that a great part of a skill in writing is the ability to monitor and direct one's own composing processes. Harris et al (2002) stated that students who are developing understandings and skills in the writing process can be assisted to become confident, independent, goal oriented, fluent writers by being taught self-regulation strategies in tandem with identified writing skills. They assure that students who experience writing difficulties don't have at hand strategies that help them accomplish specific writing tasks because they may not know how to self regulate their behavior before, during and after writing.

Chalk et al (2005) stated that Many students with learning disabilities (LD) exhibit deficiencies in the writing process. In order to achieve an adequate level of writing competence, these students must apply strategies that enable them to effectively plan, organize, write, and revise a written product. Explicit strategy instruction involving a structured style of learning has been found to increase students' writing competence (De La Paz \& Graham, 1997).

One promising approach to enhancing the writing skills of students is to directly teach them strategies for carrying out basic writing processes such as planning, drafting, and revising (Tracy et. Al.,2009).Zimmerman \& Riesemberg, (1997) stated that High levels of self-regulation are thought to be important to skilled writing because composing is an intentional activity that is quite often self-planned and selfsustained .

\section{EFL Reading:}

On the other side, Reading is an activity with a purpose. It's an interactive process that goes on between the reader and the text. , resulting in comprehension. The reader uses knowledge, skills and strategies to determine what that meaning is. Reading comprehension results when the reader knows which skills and strategies are appropriate for the type of text ( NCLR , 2004 ). Students must be able to monitor their own comprehension and apply specific reading strategies when necessary (Manson et al. , 2006).

Manson et al. (2006) stated that reading is a complex process that requires students to be engaged . They assure that good reading relies on a familiarity with text structure, background knowledge, motivation for reading, and adequate vocabulary. Moreover, Kondrate (2009) pointed out that reading skills serve as a foundation for writing. Developed and mastered, effective reading skills give people the opportunity to learn new information about the world, people, events and places, enrich vocabulary and improve their writing skills .

However, reading classrooms are still dominated by traditional classroom-based instructional interventions that don't do much to enhance reading comprehension... such interventions are failing to help students acquire the knowledge, skills, and dispositions that are crucial for life outside schools where critical thinking and self-management abilities are urgently called for. Weaknesses of traditional EFL classrooms, such as lack of authenticity, little consideration of learners' active roles in reading, and lack of adaptability of learned strategies may work against effective self-regulated reading (Ammar,2004).

Davis \& Gray ( 2007) pointed out that It's precisely self -regulated learning that sustains and deepens engaged reading and consequent comprehension. Readers must use self- regulated strategies to fully employ 
their ability to interpret or make meaning of texts.Students who have autonomy and control over their reading have opportunities to become self-regulated and exercise a focus on mastery goals.

Chen (2009) outlined that a good reader must understand the purposes and goals for reading, how to achieve those reading goals, how to adjust the reading path, and what strategies to apply to maintain good comprehension. Altogether these abilities encapsulate at least three reader-based aspects of reading comprehension: metacognitive knowledge, self-regulation, and motivational beliefs Metacognitive knowledge refers to when the reader has conscious knowledge of what is expected and what strategies to use to find a solution or a way forward. Metacognitive knowledge includes declarative knowledge (knowing what strategies to employ), procedural knowledge (how to employ the strategies), and conditional knowledge (knowing when and why the strategies should be employed)

Metacognitive knowledge is necessary for the reader to self-direct, self-monitor, and self-regulate reading performance, all of which are associated with the readers' executive control of the reading process and functions. When readers can employ strategies and understand the benefits of using particular strategies, they typically have higher motivational beliefs and self-efficacy (Westby, 2004).

Chen (2009) reported that when processing a print text, the reader's prior knowledge plays a central role in the reading comprehension process . For example, the reader has to make sense of the words based on what is already known .Consequently, reading comprehension is influenced by the reader's knowledge of the reading topics and his/her familiarity with the central concepts of a passage. Prior knowledge helps the reader to predict words and particular types of information, and this knowledge in turn helps the reader to monitor the comprehension process In addition, the reader uses prior knowledge to query the ideas in the text, ask questions, make inferences, construct meanings and images, and summarize what has been read in the text. These procedural actions that the reader takes are called "strategies," and prior knowledge influences the reader's employment of sense-making strategies in the planning and monitoring stages of the comprehension process... The skilled reader applies a broad range of processes and strategies designed to construct meaning.....

When teachers apply self-regulated learning, the following list of guidelines should be taken into account:

1. Understand that teachers need to allow students to take responsibility in their learning by emphasizing choice

2. Anticipate student to question about their information, strategies, skills, etc.

3. Teachers also need to understand that younger students need guidance when outlining their desired goals

4. Model the desired skills or strategies

5. Record students' progressions

6. Encourage and support students when their SRL strategies have been misused or ineffective

7. Break tasks down into individual mechanisms

8. Provide positive and negative corrective feedback to students at each step

9. Maintain authentic assessments within student performance

Chen (2009) stated that, the self-regulated reader sets up realistic reading goals, monitors his/her progress, and appreciates the results. The reader may also regulate his/her knowledge-seeking process and evaluate his/her strategy use to ensure the comprehension of texts. That is, good readers self-regulate their reading so as to construct meaning from text. They make predictions about the content of text based on prior knowledge, ask themselves questions and look for answers in text, make inferences as reading proceeds, construct mental images consistent with the relationships mentioned in text, seek clarification when confused, and summarize (Pressley, 2000; Pressley \& Afflerbach, 1995).

Pressley (2002) ,Pressley \& Afflerbach, (1995) and Pressley \& Wharton (1997) stated that the expert reader is active in applying a wide range of reading strategies and processes that are suitable for the different phases of reading, including before, during, and after reading.

\section{The relationship between reading and writing :}

Although much research has shown the importance of developing engaged, self-regulated, readers and writers, few researchers have investigated classroom practices that facilitate and guide this growth (Horner and O'Connor ,2007). Recent years have witnessed an increasing emphasis on the development of students' literacy skills - especially reading and writing.Self-regulation helps to promote reading and writing achievement ( Schunk and Zimmerman ,2007).

Ibrahim (2006) pointed out that the integration between reading and writing was first developed for native English learners. Students read articles and then react to their reading by writing compositions . This link is important as reading inspires students, introduces them to great ideas and improves their ability to think . Moreover, reading gives students something to talk about, encourages them to retrieve the personal background knowledge. Reading also gives students something to write about. It's not logical to separate reading from 
writing because active process in one domain may lead to the activation of the other domain . These views agree with Vandrick (2003) who assured that the integration of reading and writing helps students develop positive attitudes to writing and to language learning.

Ibrahim (2006) assumed that if writing is taught through reading texts, students will gain ideas through which they can write different topics. Moreover, students will have a model for their own writing . They do read not only to understand the gist of the topic, but to write about the ideas they get. Students in the reading/writing classrooms have the freedom in writing, and furthermore they have the models to imitate and copy . This helps them experience positive attitudes towards writing.

\section{Self-Regulation:}

Orhan $(2007,391)$ defined self-regulation as "the ways in which learners take control of their own learning “. Pintrich (2000) indicated that self-regulation is an active constructive process whereby learners set goals for their learning and then attempt to monitor, regulate and control their cognition, motivation and behavior. Self-regulation skills can be taught, learned, and controlled.

Zimmerman (1989;4) pointed out that "students can be described as self regulated to the degree that they are meta cognitively and behaviorally active participants in their own learning process ".Such students personally initiate and direct their own efforts to acquire knowledge and skill rather than relying on teachers.

The main aspect of self - regulation is metacognition. Metacognition refers to awareness, knowledge and control of cognition. It's the highest level of mental activity involving knowledge, awareness, and control of one's lower level cognitive skills, operations and strategies (Abdel Rahman, 2007). The three processes that make up metacognitive self- regulatory activities are : planning. Monitoring, and regulating (Printich et al. 1991) . Those who use these skills are called self-regulated learners. Being engaged in metacognition, is a feature of good self regulated learners(Wikipedia)

Students can be taught to become more self regulated learners by acquiring specific strategies that are both successful for them and that enable them to increase control over their own behavior and environment . Most researchers agree that the best learning occurs when someone carefully observes and considers his own behavior and acts upon what he has learned.

The concepts of metacognition, self-regulation, and self-regulated learning have been growing in dominance in educational theory, research, and practice (Kaplan,2008). Other educators (e.g., Collins, 1994; Leahey and Harris, 1997; Maitland, 2000) expand the definition of metacognition to include self-regulation of one's own cognition. As defined by Leahey and Harris (1997) metacognition is "the knowledge, awareness, and monitoring of one's own cognition" (p. 221).

Knowledge about metacognitive strategies — often referred to as self-regulation strategies--refers to the reader's knowledge about the executive processes he or she employs before, during, and after reading. Such executive strategies are considered by many educators (e.g., Collins, 1994; Maitland, 2000; Urquhart and Weir, 1998) as crucial for reading comprehension.

Perry etal. (2007) pointed out that effectively self-regulated learners are metacognitive, motivated and strategic. They exercise Metacognition by analyzing the demands of tasks in relation to their strengths and weaknesses as learners and then regulating their behavior in ways that optimize their learning processes and products.

Among the numerous metacognitive strategies, there are three main strategies that receive primary emphasis in the area of reading: (1) planning, (2) self-monitoring, and (3) self-assessment. According to Zimmerman (1989) self regulated learning involves the regulation of three general aspects of academic learning :

1. Self-regulation of behavior

2. Self-regulation of motivation

3. Self-regulation of cognition.

Zimmerman (1989, 2000,2002) developed a cyclical model of self regulation from social-cognitive theory and research. He suggested a cyclical model of self-regulation consisting of three phases :

\section{The Forethought Phase (reaction) :}

This phase precedes the action performance ; sets the stage for action, maps out the tasks to minimize the unknown and helps to develop a positive mindset. Students in the forethought phase use goal setting and strategic planning to self- regulate (Davis \& Gray ,2007).

Students must consider the following :

- When will they start?

- Where will they do the work?

- How will they get started?

- What conditions will help or hinder their learning activities are part of this phase? 
There are two major classes of forethought phase processes : task analysis and self- motivation .

Task analysis involves goal setting and strategic planning .

Self- motivation stems from students' beliefs about learning, such as self -efficacy beliefs about having the personal capability to learn .

\section{The Performance Phase :}

This phase refers to processes that occur during behavioral implementation. Students are asked to consider the following:

- Are students accomplishing what they hoped to do?

- Are they being distracted?

- Is this taking more time than they thought? Under what conditions do they accomplish the most?

- What questions can they ask themselves while they are working ?

- How can they encourage themselves to keep working?

During reading students in this phase use their background knowledge and selective strategies to understand and comprehend the text(Davis \& Gray ,2007).

Performance phase processes fall into two major classes : self- control and self- observation.Selfcontrol refers to the deployment of specific methods or strategies that were selected during the forethought phase. Self -observation refers to self- recording personal events or self -experimentation to find out the cause of these events.

\section{The self- reflection phase:}

This phase refers to processes that occur after each learning effort. It's a self- evaluation of outcomes compared to goals . Students' self- reflection brings them back to evaluate and understand their own performance (Davis \& Gray,2007). Zimmerman (1989) emphasized that students who evaluate their performance are successful at self-regulating . Students who are unaware of the need to self- evaluate tend to have difficulty in regulating their learning .

There are two major classes of self- reflection phase processes: self -judgment and self- reaction. One form of self- judgment, self- evaluation, refers to comparisons of self - observed performances against some standard

One form of self- reaction involves self- satisfaction and positive affect regarding one's performance. The three phases are shown in the following figure:
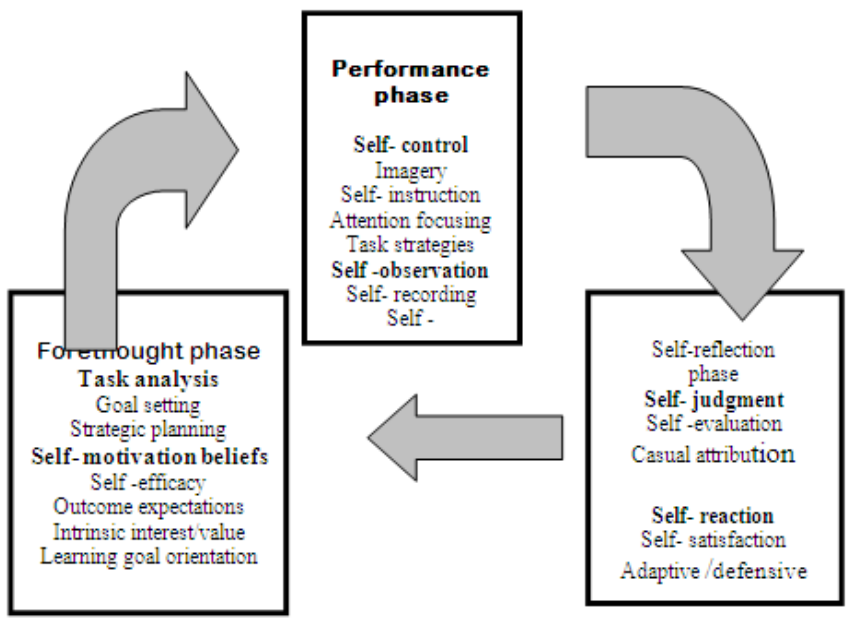

Figure 1 : phases and sub processes of self-regulation . From B.J. Zimmerman and M. Campillo (in press) . "Motivating self regulated problem solvers." In J. E. Davidson and Robert Sternberg (Eds). The Nature of Problem Solving. New York. Cambridge University Press.

The view of self-regulation is cyclical in that self reflections from prior efforts to learn affect subsequent forethought processes (Zimmerman 2002) . A cycle is completed when the self-reflection processes impact forethought phase processes during future learning attempts. It should be noted that these phases are cyclical in that feedback from previous performances is used to make adjustments during future learning efforts and attempts (Zimmerman, 2000). 
Accodring to Zimmerman (1989), self-regulated learning strategies are actions and processes directed at acquiring information or skill that involves agency, purpose and instrumentally perceptions by learners. They include such methods as organizing and transforming information, self consequating, seeking information and rehearsing or using memory aids. Research by Zimmerman and others strongly suggests that self-regulation skills can be taught, learned and controlled.

Reis (2004) reported that self-regulation strategies fall into three categories:

1. Personal strategies :

They include :

- Organizing and transforming information

- Planning and setting goals

- Keeping records and monitoring

- Written or verbal rehearsing and memorizing

2. Behavioral strategies:

They involve students checking their own progress or quality of work by examining the actions they take during the learning process.

Actions include self evaluating and self consequating .

3. Environmental strategies:

They involve seeking assistance and structuring of the physical study environment, such as ;

- Seeking information from library or internet

- Environmental structuring

Bergin et al. (no date) defined self-regulated learning as the degree to which learners are meta cognitively, motivationally and behaviorally active participants in their own academic learning.

They reported that the complete model of self regulated learning should incorporate cognitive and metacognitive strategies and motivational components.

- Cognitive strategies include rehearsal, elaboration and organization strategies.

- Metacognitive strategies include planning, monitoring and regulating cognition.

One of the instructional interventions with the strongest and most consistent research base is SRSD ,pioneered by Steve Graham and Karen Harris at the university of Maryland . It has been used in spelling, reading and math, but the area receiving the most focused attention has been SRSD in writing. SRSD is a method designed to help students learn and use the strategies used by skilled writers. SRSD is more than simply strategy instruction. It encourage students to monitor, evaluate and revise their writing, prompting self regulation skills, increasing content knowledge and improving motivation (Luke , 2006)

\section{Srsd}

Harris and Graham's SRSD model is a theoretically integrative approach, rather than an approach based on a single theory, such as social cognitive theory (although social cognitive theory has been a major influence). An underlying premise of SRSD is the need to integrate multiple lines of research from multiple theoretical perspectives in order to develop powerful interventions for students who face significant academic challenges (Harris, 1982).

The primary focus of SRSD is teaching students strategies for successfully completing an academic task. SRSD is based on the belief that the development of self-regulation processes is an important part of learning and maturing and that self-regulatory mechanisms can be fostered and improved through instruction (Harris, Graham, Mason, \& Saddler, 2002).

In the SRSD approach to strategies instruction, Self-regulation is addressed by teaching students how to set goals, self-monitor, use self-instructions, self-evaluate, and self-reinforce. Content knowledge is enhanced by teaching relevant information and skills students need to utilize the strategies or self-regulation procedures. Motivation is strengthened by development of attributions for effort and the use of powerful writing strategies, Zito et al (2007). Thus, SRSD is responsive to students who struggle with learning because it addresses their multiple cognitive, behavioural, and affective challenges (Harris et al., 2003).

The major goals of SRSD as related to writing include helping writers (a) master the higher-level cognitive processes involved in writing; (b) develop autonomous, reflective, self-regulated use of effective writing strategies; and (c) form positive attitudes about writing and about themselves as writers (Harris, 1982). 
Stages of Self-Regulated Strategy Development (SRSD):

Graham And Harris (1999) organized SRSD into six instructional stages :

\section{Stage 1: Develop background knowledge (Class)}

Teacher and students work together during stage one to develop background knowledge . Students think about what they know about the topic and add additional information

\section{Stage 2: Discuss it ( class)}

Students discuss what they have learned with one another with their teacher; they then discuss a specific writing strategy. The teacher introduces, describes and discusses strategies to be used in writing .

\section{Stage 3: Modeling of the strategy (teacher)}

Students observe the teacher modeling the strategy as well as cognitive self talk. The teacher models aloud how to use the specific writing strategy using self-instruction.

\section{Stage 4: Memorization of the strategy (student)}

Students memorize the steps of the strategy . Peer practice can be effective for supporting younger students who struggle to memorize (Manson et al , 2002)

\section{Stage 5: Collaborative practice (teacher \& class)}

Students begin to write using the writing strategy. Is the student struggling, the student and the teacher should collaboratively plan and write gradually shifting control to the student (Manson et at 2002 ). Students are encouraged to move towards self instruction to monitor their progress. Self-regulation procedures are introduced.

\section{Stage 6: Independent performance (student)}

Students should now be quite willing and able to plan their writing and use the strategy as well as instructions effectively and independently.

In turn, these instructional stages are meshed with four general strategies that students are taught to use on their own (hence, the term self - regulation):

1. Goal setting

2. Self-instruction (e.g., talk-aloud)

3. Self-monitoring

4. Self-reinforcement

Findings of studies investigating the effectiveness of the SRSD model of instruction with students with LD demonstrate improvements in four main areas: quality of writing, knowledge of writing, approach to writing, and self-efficacy regarding writing (Graham \& Harris, 2003; Harris \& Graham, 1999; Harris, Graham, Mason, \& Saddler, 2002; Harris et al., 2004) this is due to the influence of social cognitive theory in the original and ongoing development of the SRSD model Zito et al (2007).

Struggling writers don't respond to terms as brainstorm, plan, draft and revise. They need personal strategies that are specific and concrete. SRSD instruction helps students by offering concrete models for what has to happen in the mind (Graham \& Harris ,2007)

Baily (2007) explored self-regulated strategy development (SRSD), a proven strategy that is effective in improving the writing in students with learning disabilities. SRSD is an explicit, structured approach to teaching writing and strives to help students develop knowledge of writing and the strategies involved in the writing process, to support students in the ongoing development of the abilities needed to monitor and manage their writing, and to promote students' development of positive attitude about writing and about themselves as writers.

Harris \& Graham (2005) stated that the goal of SRSD is mastery of higher level cognitive processes involved in composing autonomous, reflective and self regulated use of effective writing strategies; knowledge of the characteristics of good writing and positive attitudes. Research show that as students writing improves, self efficacy, attitudes towards writing undergo positive change as well .The purpose of SRSD is to explicitly teach students strategies for accomplishing writing tasks as well as procedures for regulating these strategies.

Graham \& Harris,( 2005); Alexander,Graham, \& Harris, (1996) stated that the SRSD approach to strategies instruction views learning as a complex process that relies on changes that occur in the learners' skills, self-regulation, strategic knowledge, domain-specific knowledge and abilities, and motivation . 
SRSD has been researched across several academic domains, including reading; however, most research has been done in composition (Wong et al. , 2003)

Graham and Harris (1996) have conducted a research program examining the application of Self Regulated Strategy Development (SRSD) model to the teaching of writing .

Essa (2009) stated that SRSD helps students collaborate in the development of strategies for planning and revising as well as in developing procedures for regulating the use of these strategies, the writing task and individual cognitive and behavioral characteristics that may impede writing performance. He pointed out that this approach has been successful in helping students develop strategies for brain storming, semantic webbing, using text structure to generate possible writing content, setting goals, peer response in revising and revising for both mechanics and substance .

Harris \& Graham (2005) assured that SRSD is the most effective of all strategies instruction approaches . It helps struggling students develop both writing strategies and critical strategies for selfregulation of the writing process.

Lane et al. (2008) used a general planning strategy that included three steps to teach studets represented by the mnemonic POW ; pick my ideas, organize my notes and write and say more (continue to modify and upgrade the plane while writing).

Many studies conducted on writing using SRSD to support writing improvements suggested that SRSD has a strong impact on improving writing performance in four areas :

1. quality

2. writing knowledge

3. approach to writing

4. self-efficacy

( Harris et al , 2003)

Manson et. al. (2006) stated that SRSD is a structural instructional approach that incorporates (a) preskill development, (b) discussion of strategy usage and how it helps with reading, (c) teacher cognitive modeling, (d) strategy step memorization, (e) student and teacher collaborative practice, (f) partner practice and (g) independent practice. Students application of self- regulation in reading comprehension is explicitly taught fostering students' independence in strategy use.

Lane et al. (2008) conducted a study that examined the effect of self-regulated strategy development (SRSD) on the writing performance of second grade students with behavioral and writing disabilities. Students were taught how to plan and draft a story using the SRSD model. Results revealed lasting improvement in story completeness, length, and quality for all students . Graham and Perrin (2007) reported that SRSD had a strong and positive impact on the quality of writing with students in grade four through twelve .

SRSD helps students acquire writing strategies (Lerner \& Kline ,2006) . SRSD model provides an instructional approach designed to improve students' strategic behavior, knowledge and motivation (Lane et al. , 2008).

Harris and Graham (1996) stated three major goals for SRSD instruction. First, help students develop higher-level cognitive processes that are involved in academic performance. Second, help students develop powerful self-regulation strategies to monitor and manage their academic performance. Third, help students develop positive attitudes about learning and themselves as students.

Two studies of SRSD with primary grade students with poor writing skills produced strong treatment outcomes on writing quality with effect size exceeded 2.00; ( Graham, Harris and Manson, 2005; Harris et al. 2006).

Harris \& Graham (1996) stated that SRSD includes explicit development of critical self regulation strategies: goal setting, self monitoring, self instructions, self evaluation, coping and self control and self reinforcement.

\section{Goal Setting :}

The act of goal setting serves several key functions . It enhances attention, motivation and effort . Additionally, it provides information as to what's desired or required for the writing task at hand .

The process for goal setting includes five steps :

- $\quad$ Asking students to set the goal, breaking it into sub-steps as needed.

- $\quad$ Having students devising a plan for meeting the goal and assessing progress.

- $\quad$ Setting the plan into operation.

- $\quad$ Requiring students to monitor progress .

- $\quad$ Reset or revise goals as necessary. 


\section{Self-Monitoring :}

Self monitoring occurs when an individual self assesses whether a behavior has occurred and then self records the results. Self monitoring in writing occurs in three areas; attention, performance and strategy use. Self monitoring strategies are most effective with students who have the required skill but don't apply it. Difficulties in organization, attention, work initiation and work completion may be decreased through the use of self monitoring plan.

\section{Self -Instruction:}

Self- instruction involves self-speech which is self -regulatory . It may be overt or covert. Selfinstructions state criteria for success and enhance positive attitudes about the attention to the task.

\section{4 . Self -Evaluation :}

Students evaluate performance correcting errors.

\section{Coping and Self $f$ Control:}

Self -speech helps students cope and develop self -control.

\section{Self- Reinforcement :}

Students reward themselves by thinking praises such as ;" I'm getting better at this “.

De La Paz (1999) listed five points to be taken into account when teaching the SRSD model:

1. Both strategies and self-regulation procedures must be explicitly taught to the students .

2. An emphasis is placed on interactive learning between students and teacher. Students are active collaborators in the procedures of SRSD .

3. Instruction of SRSD is individualized to cater to students' personal needs.

4. SRSD is criterion-based. Students move through the stages at their own pace.

5. SRSD is an ongoing process. New skills are introduced and previously taught strategies are upgraded and reviewed.

Teacher's role while using SRSD:

Using this approach, teachers:

1. shift the responsibility to the student - e.g., encourage students to exercise choices about how to accomplish learning activities; help student shift the focus of their regulation away from the teacher and onto salient cues in the learning task

2. adopt a systematic instructional approach; a cyclic self-regulatory approach to learning

3. demonstrate model (sequence is important: student observes model, imitates, practices in structured settings, then self-regulates by adapting to changing personal and contextual conditions)

4. demonstrate effectiveness of self-regulatory techniques; keep records of student's progress

5. use verbal persuasion; support and encouragement, especially when student

Graham \& Harris (2007) stated that effective SRSD instruction requires a teacher who is enthusiastic, who will involve students collaboratively in finding their specific strategy, who will provide opportunities for students to use the strategy and who will praise and reinforce students efforts.

Self-regulation is thought to enhance writing performance in two ways. First, self-regulatory mechanisms, such as planning, monitoring, evaluating, and revising, provide building blocks or subroutines that can be assembled along with other subroutines, such as procedures for producing text, to form a program for effectively accomplishing the writing task (Scardamalia \& Bereiter, 1985). Second, the use of these mechanisms may act as change-inducing agents, leading to strategic adjustments in writing behaviour.

Lane et al. $(2008,240)$ reported that "with SRSD approach , students are explicitly taught strategies for specific writing genres and for general writing strategies ,such as good word choice, interesting opening, etc. They are taught information , vocabulary and the skills needed to use these strategies."

SRSD is designed to help students become fluent, independent, self-regulated, goal-oriented learners (Graham, Harris, \& Reid, 1992). SRSD can help writers in three ways. First, strategy usage assists students in developing knowledge about the writing process, thereby increasing the skills students need for effective planning, writing, revising, and editing. Next, students are supported in the development of the self-regulation procedures needed to monitor and manage their own writing Luke (2006) listed fundamental features of SRSD as follows: 
- Explicit and extensive strategy instruction on writing, self-regulation, and content knowledge

- Interactive learning and active collaboration

- Individualized instructional support and feedback tailored to student needs and abilities

- Self-paced learning, with proficiency demonstrations required in order to progress from one stage of instruction to the next

The continuous introduction of new strategies and novel ways to use previously taught strategies

\section{Studies related to SRSD and self-regulated learning:}

Chalk et al (2005) examined the effects of the Self-Regulated Strategy Development (SRSD) model on the writing performance of 15 high school sophomores with LD. Students were taught to apply the SRSD model as a strategy for planning and writing essays and to self-regulate their use of the strategy and the writing process. The effects of strategy instruction were highly effective .

In a study for Ammar (2004) he investigated the effects of self- regulated reading strategy developments on the prospective EFL teachers' critical reading skills and reading motivation. Findings of the study indicated that students' self-regulation of their EFL reading resulted in significant gains in their critical reading skills as well as in their motivation to read in English as a foreign language compared to the traditional reading instruction practices

Swalander \& Taube (2007)investigated the effect of self-regulated learning, as indicated by academic self-concept, motivation and learning strategies, reading attitude and family based prerequisites on reading ability. Students $(\mathrm{n}=4018)$ in the eighth grade answered the IEA reading literacy test, the self-regulated learning questionnaire and a student questionnaire about their background. The exploratory factor analysis (EFA) revealed that the self-regulated learning questionnaire did not measure the intended three dimensions, but only two: Verbal/General academic self-concept and a new dimension called Goal oriented strategies. Structural Equation Modelling ("SEM") with a cross-validation sample was conducted to determine the effects in the final model. The strongest effect on reading ability was from Verbal/General academic self-concept (beta $=0.43$ for final and beta $=0.56$ for cross-validation model). Gender differences revealed that girls read better on narrative and expository texts, had a more positive reading attitude, and more positive verbal self-concept, whereas boys had a higher academic self-concept (not domain-specific), self-efficacy, control expectation, reported more memorising, elaboration, and instrumental motivation (all differences p less than 0.001).

Sinclair (2004) identified the strategies one teacher used to support her Years 5 and 6 students develop self-regulating behaviors. How her students responded to these strategies and how they influenced students' emerging self-regulating behaviors were also identified. The study was carried out within the context of the written language strand of the English curriculum, and required the students to explore and write persuasive texts.

Cleary \& Zimmerman (2004) designed a training program, Self-Regulation Empowerment Program (SREP), that school professionals can use to empower adolescent students to engage in more positive, self motivating cycles of learning. It is a two-part approach whereby self-regulated learning coaches

(SRC) (a) use micro analytic assessment procedures to assess students' self-regulation beliefs and study strategies and (b) train students to use these strategies in a cyclical, self-regulation feedback loop. Ultimately, students learn how to set goals, select and monitor strategy effectiveness, make strategic attributions, and adjust their goals and strategies. The program was developed from social-cognitive theory and research and integrates many of the essential features of the problem-solving model. Interventions used in the SREP include graphing, cognitive modelling, cognitive coaching, and structured practice sessions. A case study is presented to illustrate procedures for implementing the program.

Pintrich \& De Groot's (1990) correlational study examined relationships between motivational orientation, self-regulated learning, and classroom academic performance for 173 seventh graders from eight science and seven English classes. A self-report measure of student self-efficacy, intrinsic value, test anxiety, self-regulation, and use of learning strategies was administered, and performance data were obtained from work on classroom assignments. Self-efficacy and intrinsic value were positively related to cognitive engagement and performance. Regression analyses revealed that, depending on the outcome measure, self-regulation, selfefficacy, and test anxiety emerged as the best predictors of performance. Intrinsic value did not have a direct influence on performance butwas strongly related to self-regulation and cognitive strategy use, regardless of prior achievement level.

Singer and Bashir (1999) conducted a research which also made use of the self-regulated approach in dealing with oral and written communication skills. This intervention was implemented on one sixteen year old student with some speech-language evaluation. Singer and Bashir believe that strategies for speaking and writing are correlated with the three sub-processes of self-regulation

Plata (2008) did a similar study regarding the use of self-regulation as a strategy in language learning. She explored Freshman Composition students' reflection in their journals to find out the role of the three-stage 
model of self-regulatory prompts in student's learning and metacognition. She collected 47 journals from two classes comprising of 22 Liberal Arts students and 25 from Engineering. Her study revealed that giving students prompts that manifest the cycle of self-regulation can increase student's awareness of their learning. Results of the study also indicate that the prompts not only give students the experience of minding their own thinking but also making them aware of the depth and breadth of their learning experience.

Hamman (2005) created a self-regulation scale in writing in which the data collected were already part of a regular course requirement, but only the students who gave consent had their measures used in the data analysis. There were 82 participants of the study, 69 females and 13 males at a large Midwestern University. This study was constructed as a descriptive study to examine beginning education majors' beliefs about writing and epistemology, as well as their reported self-regulatory behaviors. The study was initiated for gaining better understanding about students' attitudes about writing and learning, and as well as determining if these beliefs were related to self-regulated behaviors in writing tasks. It was hoped that the results from this study would provide the College of Education with knowledge for course instructors to better support students in writing tasks, as well as to lead to continued research in this area.

Turingan (2009) investigated a cross-cultural comparison of self-regulated learning (SRL) skills between Korean and Filipino college students. Specifically, it identified and analyzed the motivational and learning strategies adopted by Korean and Filipino students. To measure their SRL skills, the Motivated Strategies for Learning Questionnaire was administered.

Results of this study showed that the degree of Filipino students' SRL skills was higher than one of Korean students.

Cultural and educational contexts of the two countries were examined to identify possible factors underlying the differences between two countries' college students in SRL skills.

Bail et al. (2008) conducted a study, the purpose of which was to determine the effects of completion of a self-regulated learning course on long-term academic outcomes of undergraduate students from a university program to support underprepared undergraduate students. These students were compared to a group of students from the same program who were carefully selected to be similar in terms of number of prior academic credits, prior cumulative GPA, gender, and number of transfer credits. Students who took the course had significantly higher cumulative GPAs four semesters afterwards, significantly higher odds of graduation, and significantly lower odds of receiving one or more F grades in subsequent semesters. Course structure and other factors deemed central to the success of this course were identified

Yang's (2006) study was to explore the effects of embedded strategies on promoting the use of selfregulated learning strategies (SRLS) in an online learning environment. Cognitive strategies, performance control strategies, and self-efficacy strategies among SRLS were employed as embedded strategies into online learning. Thirty-four college students participated in the study. They were taught in online settings for 16 hours over 8 weeks. With two hours per week, one hour was assigned to learning contents, and the other for group discussions with four or five members in each group. SRLS questionnaires were administered before and after online learning. Results revealed that students' use of cognitive strategies and performance control strategies have been improved during online learning, but their use of self-efficacy strategies have not. Findings from this study provide important suggestions for design and development of learning environments to promote the use or acquisition of students' self-regulated learning strategies.

Orhan (2007) examined the effect of the blended learning environment on learners' self- efficacy for learning and performance and self -regulated learning strategies. In the study, students used different selfregulated strategies such as self -evaluating, appreciating their classmates' critics on their work, monitoring their work by comparing it with that of other students in the class and monitoring their study exams through follow up quizzes; monitoring their study time, keeping journals in a blended learning environment to help themselves to improve their use of self -regulated strategies. Research results revealed that students selfefficacy and self-regulated strategies perception benefited from the blended learning environment with selfregulated learning strategies.

Mousoulides and Philippou (2005) examined the relationships between motivational beliefs, self regulation strategies use, and mathematics achievement in Cypriot pre-service teachers. Specifically, a model depicting connections and causal relations among cognitive and affective factors was developed. It was tested on the basis of self report data collected from 194 pre-service teachers using a modified version of MSLQ and a mathematics achievement test. It was found that the data fits the theoretical model very well, meaning that the model explains the structure of the above relationships, with self-efficacy being a strong predictor of mathematics achievement and self-regulation strategies use having a negative effect on achievement.

A thoughtful, effective integration of diverse, validated approaches to learning, regardless of whether or not the disciplines from which they originated are viewed by some as discordant (such as affective, behavioral, and cognitive theories), has been key to the development of SRSD (Zito et al 2007) . 


\section{Conclusion:}

College students are graduated every year, most of them are of low proficiency in English language skills. One of the reasons for this problem may be the use of ineffective methods and approaches in developing EFL skills and the neglect of participating students in the learning teaching process and evaluation. An importance should be given to the development of EFL skills among Saudi college students. Different approaches and strategies should be examined in order to achieve this goal. In order to obtain the desired results, students should participate in the learning process themselves. Self- regulated learning focuses on students' motivation and attitudes, interactive learning and active collaboration. Studies that proved positive results using SRSD in developing writing skills depended on students' self -evaluation, self control,and selfreinforcement.

\section{Recommendations}

The following recommendations are presented to be followed in the Saudi Context:

- More considerations should be given to recent trends in the field of ELT that develop EFL skills .

- Methods and approaches that give special importance to students' needs and abilities should be examined .

- Focus should move from the teacher to the students to help them be active in the learning process.

- A relationship between EFL students' motivation and their self- regulation should be examined.

\section{References}

[1]. Abdel-Hack, I. M. (2002). The Effectiveness of a Task-based Learning Approach on EFL Students' Writing Production. Ocational papers in the Development of English Language Education.(Issued by Center for Developing English Language Teaching " CDELT" , No. 34, pp. 193-231.

[2]. Abdel-Hack, I. M. (2004). The Effectiveness of Using Journal Writing in Developing EFL Major Critical Thinking Disposition and Writing Performance . " Journal of Studies in Curricula and Instruction, ( Issued by : Faculty of Education, Ain Shams University), No.97,pp.4-33.

[3]. Adams, M. J., Treiman, R., \& Pressley, M., (2000). Reading, writing, and literacy. In I. E. Sigel \& K. A. Renninger, (Eds.), Handbook of child psychology: Vol. 4. Child psychology in practice (pp. 275-355). New York: Wiley.

[4]. Ai, M. (1995). The effects of cultural background knowledge on graduate students' response to reading American and Chinese short stories in English and Chinese. DAI-A, 55(1), 3114.

[5]. Alderson, J. (2000). Assessing Reading. Cambridge: Cambridge University Press

[6]. Alexander, P., Graham, S., \& Harris, K. R. (1996). A perspective on strategy research: Process and prospects. Educational Psychology Review, 10, 129-154.

[7]. Aly, A. S. (2001). Developing the Composition Writing Skills through adopting the Whole Language Approach for the Prep Stage Experimental School Pupils. Unpublished M.A. Thesis . Faculty of Education, Ain Shams University.

[8]. Ammar,A.M.I. (2004). The Effects of Self-regulated Reading Strategy Development on the Prospective EFL Teachers' Critical Reading Skills and Reading Motivation .

[9]. Anderson, N. (2001). The Role of Metacognition in Second Language Teaching and Learning (On-Line). Available at: eric@cal.org.

[10]. Bail ,F. T. Zhang,S. T. and Gary, T. (2008). Effects of a self-regulated learning course on the academic performance and graduation rate of college students in an academic support program.Journal of College Reading and Learning

[11]. Bailey, K. (2007). Self-Regulated Strategy Development Reasearch paper presented at the university of British Colombia.

[12]. Ballantyne, M. (1993). The effects of narrative and expository discourse on the reading comprehension of of middle school-aged good and poor readers. DAI-A, 45(11), 4046.

[13]. Block, C. C., \& Pressley, M. (2001). Comprehension instruction: Research-based best practices. New York: Guilford

[14]. Bouffard, T and Vezeau, C. (1998). The developing self-system and self-regulation of primary school children. In Michael D. Ferrari et al. (Eds.), Self-Awareness: Its Nature and Development (pp. 246-272). New York: The Guillford Press.

[15]. Bouffard-Bouchard, T. (1995). Effect of activating conditional knowledge on self-efficacy and comprehension monitoring. International Journal of Behavioral Development, 17 (3), 577-592.

[16]. Brenton, H. (1997). Metacognitive strategies and attribution training with children displaying attentional problems. DAI-A, 58(10), 3885.

[17]. Brown, L. (1993). A study of the relationships among self-concept, reading attitude and reading comprehension in second grade readers. DAI-A, 31(4), 1468

[18]. Buhrke,L.; Henkels,L. ; Klene,J \& Pfister,H. (2002). Improving Fourth Grade Students' Writing Skills and Attitudes. MA. Action Research Project . Saint Xavier University and Kkylight Proffessional Development Field-based Master Degree( An Online ERIC Database Fulltext No. ED 471788.

[19]. Carrell, P. (1992). Awareness of text structure: Effects on recall. Language Learning, 42(1), 1-20. Chan, L. (1994). Relationship of motivation, strategic learning, and reading achievement in grades 5, 7, and 9. Journal of Experimental Education, 62(4), 319-339.

[20]. Chalk ,F.C. ; Hagan-Burke,S. \& Burke, M. (2005). The Effects Of Self-Regulated Strategy Development On The Writing Process For High School Students With Learning Disabilities. Learning Disabiiity Quarteriy. 28,pp. 75-87.

[21]. Chen, C. (1995). Differences between poor and good readers and effects of story-structure knowledge training on poor readers. DAI-A, 57(1), 109.

[22]. Chen,H.Y. (2009). Online Reading Comprehension Strategies Among General And Special Education Elementary And Middle School Students. A dissertation Submitted to Michigan state university In partial fulfillment of the requirements For the degree of Doctor of philosophy Counseling, educational psychology and special education.

[23]. Chen,C.S. (2002). Self-regulated Learning Strategies and

[24]. Achievement in an Introduction to Information Systems Course. Information Technology, Learning, and Performance Journal, 20 ( $1), 11-25$.

[25]. Clapham, C. (1998). The effect of language proficiency and background knowledge on EAP students' reading comprehension. In A. Kunnan (Ed.), Validation in Language Assessment (pp. 141-168). Mahwah, NJ: Lawrence Erlbaum Associates, Publishers. 
[26]. Clearly, T and Zimmerman ,B. (2004). Self-Regulation Empowerment Program: A School-Based Program To Enhance SelfRegulated And Self-Motivated Cycles Of Student Learning. Psychology in the Schools, 41(5).

[27]. Collins ,N.D. (1994). Metacognition and Reading to Learn. (Eric database no. EDO-CS-94-09

[28]. Conner, J. (2002). Monitoring Comprehension. (On-Line). Available at: http://www.indiana.edu/ 151//monitoring. Html.

[29]. Davis,S.G. \& Gray,E.S. (2007). Going Beyond Teast Taking Strategies: Building Self- Regulated Students and Teachers. Journal of Curriculum and Instruction ,1(1), 31-47

[30]. De La Paz,S. (1999). Teaching Writing Strategies And Self Regulation Procedures To Middle School Students With Learning Disabilities. Focus on exceptional children,31,1-16.

[31]. De La Paz, D. \& Graham, S. (1997). Strategy Instruction in Planning : Effects of the Writing Performance and Behaviour of Students with Learning Difficulties; Exceptional Children, 63,167-181.

[32]. Delano M. E. (2007). Improving Written Language Performance Of Adolescents With Asperger Syndrome. Journal Of Applied Behavior Analysis, 40(2), 345-351.

[33]. Droop, M. and Verhoeven, V. (1998). Background knowledge, linguistic complexity, and second language reading comprehension. Journal of Literacy Research, 30(2), 253-271.

[34]. Duke, N. K., \& Pearson, P. D. (2002). Effective practices for developing reading comprehension.In A. E. Farstrup \& S. J. Samuels (Eds.), What research has to say about reading instruction ( $3^{\text {rd }}$ ed, pp. $\left.205-242\right)$. Newark, DE: International Reading Association.

[35]. Dymoc, S. (1998). A comparison study of the effects of text structure training, reading practice, and guided reading on reading comprehension. National Reading Conference Yearbook, 47, 90-102.

[36]. El Koumy ,A.A. (2004). Metacognition and Reading Comprehension: Current Trends in Theory and Research. Anglo Egyptian Books. Cairo, Egypt.

[37]. Enrlich, M., Kurtz, C., and Loridant, C. (1993). Cognitive and metacognitive determinants of reading comprehension in good and poor readers. Journal of Reading Behavior, 25(4), 365-381.

[38]. Essa,M.A. (2007). The Effectiveness Of A Program Based On The Self Regulated Strategy Development On Writing Performance, Writing Self Efficacy And Attributions Of Writing Disabled First Year Secondary School Students . Journal of educational psychology, Tanta University,,38(2), 75-93.

[39]. Essa,M.A. (2009) . The Effectiveness of a Program Based on Self-Regulated Strategy Development on the Writing Skills of Writing Disabled Secondary School Students. Electronic Journal of Research in Educational Psychology , 7(1), 5-24.

[40]. Fan, M. (1999). An investigation into the beliefs and strategies of Hong Kong students in the learning of English. Education Journal, 27(2), 56-81.

[41]. Fan, H. C. (2009). The Effectiveness of Metacognitive Strategies in Facilitating Taiwanese University Learners in EFL Reading Comprehension. Ph.D. Thesis, Department of Curriculum and Teaching ,Faculty of the Graduate School ,University of Kansas ,partial fulfillment of the requirements for the degree of Doctor of Philosophy

[42]. Faris, K. and Smeltzer, L. (1997). Schema theory compared to text-centered theory as an explanation for the reader's understanding of a business message. Journal of Business Communication, 34(1), 7-26.

[43]. Flavell,G.H. (1976). Metacognitive aspects of problem solving. In L.B. Resnik (ed), the nature of intelligence (pp.231-236). Hillsdale,N...J.:Erlbaum .

[44]. García1,J.N. \& Fidalgo,R. (2008). Orchestration ofWriting Processes and Writing Products: A Comparison of Sixth-Grade Students With and Without Learning Disabilities. Learning Disabilities: A Contemporary Journal, 6(2), 77-98.

[45]. Graham, S. (2006b). Writing. In P. Alexander \& P. Winne (Eds.), Handbook of educational psychology, 457-478.Mahwah, NJ: Erlbaum.

[46]. Graham,S. \&Harris,K.R. (1999). Assessment And Intervension In Overcoming Writing Difficulties: An Illustration From The Self Regulated Strategy Development Model. Language Speech And Hearing Services In Schools, 30, 255-264.

[47]. Graham,S. \&Harris,K.R. (2005).Writing Better: Teaching Writing Processes And Self Regulation To Students With Learning Problems . Baltimore, MD: Brookes .

[48]. Graham, S. \& Harris, K. R. (1994). The role and development of self-regulation in the writing process. In D. H. Schunk \& B. J. Zimmerman (Eds.), Self-regulation of learning and performance: Issues and educational applications (pp. 203-228).Hillsdale, NJ: Erlbaum.

[49]. Graham,S.\& Harris,K.R. (1996). Teaching Writing Strategies Within the Context of a Whole Language Class.In EMcIntyre \& M. Pressely(Eds), Balanced Instruction: Strategies and Skills in whole language pp(155-175). NewYork. Christopher Gordon.

[50]. Graham,S.\& Harris,K.R. (2003).Students With Learning Disabilities And The Process Of Writing : A Meta-Analysisofsrsd Studies. In H.L. Swanson, K. R. Harris \& S. Gram. Eds.),Handbook of Learning disabilities(pp.323-344)NewYork: the Gulford Press.

[51]. Graham \& Harris (2007). Helping Struggling Writers : Self Regulated Strategy Development (SRSAD) Instruction .Available at:http://www.mde.k12.mss.us/acad1/writing better.ppt

[52]. Graham, S. \& Harris, K. R. (2005). Improving the writing performance of young struggling writers: Theoretical and programmatic research from the Center to Accelerate Student Learning. Journal of Special Education, 39, 19-33.

[53]. Graham,S. \& Perin,D. (2007). A Meta Analysis Of Writing Instruction For Adolescent Students. Journal of Educational Psychology, 99, 445-476.

[54]. Graham,S. \& Harris, K. (2000). The Role of Self-Regulation and Transcription Skills in Writing and Writing Development. Educational Psychologist, 35(1), 3-12

[55]. Graham' S.;Harris' K. and Mason' L. (2005). Improving the writing performance, knowledge, and self-efficacy of struggling young writers: The effects of self-regulated strategy development. Contemporary Educational Psychology,30(2), 207-241

[56]. Graham, S., Harris, K. R., \& Reid, R. (1992). Developing self-regulated learners. Focus on Exceptional Children, 24(6), 1-16.

[57]. Graham, S., Harris, K. R., \& Troia, G. (1998). Writing and self-regulation: Cases from the self-regulated strategy development model. In D. H. Schunk \& B. J. Zimmerman (Eds.), Self-regulated learning: From teaching to self-reflective practices (p. 30). New York: Guilford.

[58]. Griffith, P. and Olson, M. (1992). Phonemic awareness helps beginning readers break the code. Reading Teacher, 45(7), 516-523.

[59]. Hamman, L. (2005).Self-Regulation In Academic Writing Tasks. International Journal of Teaching and Learning in Higher Education, 17(1),15-26.

[60]. Harris, K. R. (1982). Cognitive behavior modification: Application with exceptional students. Focus on Exceptional Children, IS, 116.

[61]. Harris, K.R., Graham,S. \& Manson,L. (2003). Self regulated Strategy Development in the Classroom: Part of a Balanced Approach to Writing Instruction for Students with Disabilities. Focus on Exceptional Children,35(7), 1-16.

[62]. Harris, K. R. \& Graham, S. (1999). Programmatic intervention research: Illustrations from the evolution of self-regulated strategy development. Learning Disability Quarterly, 22, 251-262. 
[63]. Harris,K. \& Graham,S. (1996). Making The Writing Process Work: Strategies For Composition And Self Regulation ( $2^{\text {nd }}$ Ed.). Cambridge :Brookline books.

[64]. Harris,K. ; Graham,S. and Mason, L. (2006). Improving Writing Knowledge and Motivation of Struggling Young Writers :Effects of Self-Regulated Strategy Development with and without Peer Support. American Educational Research Journal ,42(2), 295-340.

[65]. Harris, K.R., Graham, S., Mason, L.H., Saddler, B. (2002). Developing self-regulated writers. Theory Into Practice, 41(2), 110-115.

[66]. Harris, K. R., Reid, R. R., \& Graham, S. (2004). Self-regulation among students with LD and ADHD. In B. Y. L. Wong (Ed.), Learning about learning disabilities (3rd ed., pp. 167-195). San Diego, CA: Elsevier Academic.

[67]. He, T. (2001). Contrastive goal orientation in an EFL reading context: Influences on reading strategy use and comprehension patterns. TESL-EJ, 5(1), 1-18.

[68]. Helal ,E. A.(2003). A Proposed Self Access Reading Program for Developing English Language Writing Skills for First Year Secondary Students . Unpublished MA. Thesis, Women's Colege for Arts, Science and Education, Ain Shams University.

[69]. Helsel, L., Greenberg, D. (2007). Helping Struggling Writers Succeed: A Self-Regulated Strategy Instruction Program. Reading Teacher, 60(8), 752-760.

[70]. Hertzog, C. (2002). Metacognition in older adults: Implication application. In T. J. Perfect and L. Schwartz (Eds.), Applied Metacognition (pp. 169-183). London: Cambridge University Press.

[71]. Hilden, K.R., \& Pressley, M. (2007). Self-regulation through transactional strategies instruction. Reading and Writing Quarterly: Overcoming learning difficulties, 23, 51-75.

[72]. Hopkins, C. (2002).Improving Tenth Grade Students Five Paragraph Essay Writing Skills Using Various Writing Strategies, Guided Assignments And Portfolios for Growth. M.A. in Teaching Language Action Reasearch Project . Nova Southeastern University. ( An Online ERIC Database Fulltext No. ED 471633.)

[73]. Horner ,S.L.and O'Connor,E.A.(2007). Introduction: Helping Beginning And Struggling Readers And Writers To Develop SelfRegulated Strategies. Reading \& Writing Quarterly, 23: 1-5.

[74]. Houtveena A. A. and van de Grift W. J. (2007). Effects of Metacognitive Strategy Instruction and Instruction Time on Reading Comprehension. School Effectiveness and School Improvement, 18, (2), 173 - 190.

[75]. Ibrahim,H. (2006). The Effect Of Using The Reading For Writing Approach On Developing The Writing Ability Of Egyptian EFL Learners And Their Attitudes Towards Writing. Scientific Methodologies In Educational Research

[76]. Isaacs, M. (1996). Levels of phonemic awareness and their relationship to reading and spelling. DAI-A, 58(1), 0072. Kanlapan,M.T.C. \& Velasco,J. (2009). Constructing a Self -regulation Scale Contextualized In Writing. TESOLJournal ,1 , 79-94.

[77]. Jacobs,G. (2004). A Classroom Investigation of the Growth of Metacognitive Awareness in Kindergarten Children through the Writing Process . Early Childhood Education Journal, 32(1), pp.17-23.

[78]. Jacobson,L.T \& Reid,R. (2010). Improving the PersuasiveEssay Writing of High School Students With ADHD . JO Council fir Exceptional Children . 76( 2), 57-174.

[79]. Jung, H. (1992). The relationship between adult second language readers' metacognitive awareness of reading and their processes in a second language. Unpublished Ph.D. Dissertation, The University of Arizona.

[80]. Kaplan,A. (2008). Clarifying Metacognition, Self-Regulation, and Self-Regulated Learning: What's the Purpose? Educ Psychol Rev . 20:477-484.

[81]. Kolic-Vehovec , S. (2006).Metacognitive strategies and reading comprehension in elementary-school students . European Journal of Psychology of Education, 21,(4), 439-451.

[82]. Kondrat,A. (2009). Importance Of Good Writing And Reading Skills ,Effective Writing And Reading Skills For Effective Communication.available at : http://personaldevelopment.suite101.com/article.cfm/importance_of good writing

[83]. Kohonen, V., Jaatinen, R., Kaikkonen, P., and Lehtovaara, J. (2001). Experiential Learning in Foreign Language Education. Harlow: Longman.

[84]. Lane,K.L.;Harris, K.R.: Graham,S. ; Weisennbach,J.L. ; Brindle, L.\&Morphy,P. (2008). The Effects Of Self Regulated Strategy Development On The Writing Performance Of Second Grade Students With Behavioural And Writing Difficulties. Journal Of Specific Education ,.41(4), 234-253.

[85]. Leahey, T. and Harris, R. (1997). Learning and Cognition. New Jersey: Prentice Hall.

[86]. Lee, S. \& Krashen, S. (2002). Predictors of success in writing English as a foreign language: Reading, revision behavior, apprehension, and writing. College Student Journal, 36, 532-543.

[87]. Legge, J. (1994). The interrelationships among and the gender effects of parental children's attitudes toward reading, children's self-concepts as readers and children's reading comprehension. DAI-A, 34(2), 507.

[88]. Leon, J. and Carretero, M. (1995). Intervention in comprehension and memory strategies: Knowledge and use of text structure. Learning and Instruction, 5(3), 203-220.

[89]. Lerner, J., Kline, F. (2006). Learning Disabilities And Related Disorders: Characteristics And Teaching Strategies (10th ed.). Boston: Houghton Mifflin Company.

[90]. Lienemann,T. \& Reid, R. (2008) Using Self-Regulated StrategyDevelopment to Improve Expository Writing With Students With Attention Deficit Hyper activity Disorder Exceptional Children . 74 (4). 471-486.

[91]. Linderholm,T. \& , Cong, X, and Zhao ,Q. (2008). Differences In Low And High Working-Memory Capacity Readers' Cognitive And Metacognitive Processing Patterns As A Function Of Reading For Different Purposes. Reading Psychology, 29,pp.61-85.

[92]. Lin,Z. and Siriyothin,P. (2008)Effects of reading tasks on reading comprehension of Chinese EFL students: A pilot study US-China Foreign Language, 6, No.5

[93]. Luke,S.D. (2006). The Power of Strategy Instruction. The National Dissemination Center for Children with Disabilities(NDCCD)

[94]. Maitland, L. (2000). Ideas in practice: Self-regulation and metacognition in the reading lab. Journal of Developmental Education, 24(2), 26-32.

[95]. Mango,C. (2008). Reading Strategy, Amount of Writing, Metacognition, Metamemory, and Apprehension as Predictors of English Written Proficiency. Asian EFL Journal,.29(2).

[96]. Magno,C. (2009). Self-Regulation and Approaches to Learning

[97]. in English Composition Writing. TESOL Journal,1,1-16.

[98]. Maggioni, L., \& Parkinson, M. M. (2008). The role of teacher epistemic cognition, epistemic beliefs, and calibration in instruction. Educational Psychology Review. 20(4),445-462.

[99]. Manson,L.H.;Meadan,H.;Hiden,L.\& Corso,L. (2006). Expository Text Comprehension, Teaching Exceptional Children, 38(4).2752.

[100]. Martin, A. (1994). Case study of a good reader and a poor reader at the primary level: The construction of meaning DAI-A, 33(5), 1386. 
[101]. Mason, L. H. (2004). Explicit self-regulated strategy development versus reciprocal questioning: Effect on expository reading comprehension among struggling readers. Journal of Educational Psychology, 96, 283-296.

[102]. Mason, L.H., Harris, K.R., Graham, S. (2002). Every Child Has A Story To Tell: Self-Regulated Strategy Development For Story Writing. Education and Treatment of Children,. 25(4), 496- 508.

[103]. Montalvo,F.T. (2004). Self-Regulated Learning: Current and Future Directions. Electronic Journal of Research in Educational Psychology, 2(1),1-34.

[104]. Mousoulides ,N. \& Philippou,G.(2005) Students' Motivational Beliefs, Self-Regulation Strategies And Mathematics Achievement, Proceedings of the 29th Conference of the International Group for the Psychology of Mathematics Education, 3, 321-328. Melbourne: PME.

[105]. Mayer, R. E. (2001). What good is educational psychology? The case of cognition and instruction. Educational Psychologist, 36, $83-88$.

[106]. NCLRC (2004) Teaching Reading . Available at: http://www.nclrc.org/essentials/reading/reindex.htm

[107]. Nilson,M.N. \&Williamson,G.M. (2006) . The Impact Of Explicit, Self Regulatory Reading Comprehension Strategy Instruction On The Reading-Specific Efficacy,Attributions, And Affect On Students With Reading disabilities.Learning Disability Quarterly , 29 (3), 213-230.

[108]. Ono, N. (1993). Reading as inquiry: A new horizon for ESL learners. DAI-A, 53(12), 4265.

[109]. Orhan,F. (2007). Applying Self-Regulated Learning Strategies in a Blended Learning Instruction. World Applied Sciences Journal.2(4),390-398.

[110]. O'Shea, L. and O'Shea, D. (1994). A component analysis of metacognition in reading comprehension: The contribution of awareness and self-regulation. International Journal of Disability, 41(1), 15-32.

[111]. O'Sullivan, J. (1992). Reading Beliefs and Reading Achievement: A Development Study of Students from Low Income Families. ERIC Document No. ED 354505.

[112]. Pearson, U. (1994). Reading for Understanding: An Empirical Contribution to the Metacognition of Reading Comprehension. ERIC Document No. ED 381773.

[113]. Pearson, P. D., Roehler, L. R., Dole, J. A., \& Duffy, G. G. (1992). Developing expertise in reading comprehension. In S. J. Samuels \& A. E. Farstrup (Eds.), What research has to say about reading instruction (2nd edn, pp. 145 - 199). Newark, DE: International Reading Association

[114]. Perry,N.E. ; Nordby,C.J. \& Vandkamp,K.O. (2003). Promoting Self Regulating Reading and Writing at Home and School.The Elementary School Journal, 103(4), 317-338.

[115]. Pintrich, P. R., Smith, D. A., Garcia, T., \& McKeachie W. J. (1991). A manual for the use of the Motivated Strategies for Learning Questionnaire (MSLQ). National Center for Research to Improve Postsecondary Teaching and Learning. Ann Arbor: University of Michigan.

[116]. Plata, S. M. (2008). Exploring Students' Self-Assessment Following The Three-Stage Model Of Self-Regulatory Prompts In Freshman Composition. Learning Edge, 4, 3-52.

[117]. Pintrich, P.R. \& De Groot (1990). Motivational and Self Regulated Learning Components of Classroom Academic Performance .Journal of Educational Psychology. Vol.82(1), pp33-40

[118]. Pintrich, P. R. (2000). The role of goal orientation in self-regulated learning. In M. Boekaerts, P. R. Pintrich, \& M. Zeidner (Eds.), Handbook of self-regulation(451-501). New York: Academic Press

[119]. Reis,S. (2004). Self Regulated Learning And Academically Talented Students.National Association For Gifted Children (NAGC). Available at:http://www.nagc.org

[120]. Pressley, M. (2002). Metacognition and self-regulated comprehension. In A. E. Farstrup \& S. J. Samuels (Eds.), What research has to say about reading instruction, (pp. 291-309). Newark, DE: International Reading Association.

[121]. Pressley, M., \& Afflerbach, P. (1995). Verbal protocols of reading: The nature of constructively responsive reading. Hillsdale NJ: Lawrence Erlbaum Associates. through instruction. School of Psychology Review, 26, 448-467.

[122]. Ruan, J.(2004) Bilingual Chinese/English first-graders developing metacognition about writing Leteracy,pp.106-112.

[123]. Santangelo,T \& Harris,K.R. \& Graham,S. (2007). Self-Regulated Strategy Development:A Validated Model to Support Students Who Struggle with Writing . Learning Disabilities: A Contemporary Journal 5(1), 1-20.

[124]. Scardamalia, M., \& Bereiter, C. (1985). Fostering the development of self-regulation in children's knowledge processing. In S. Chipman, J. Segal, \& R. Glaser (Eds.), Thinking and learning skills: Current researcresearch and open questions (Vol. 2, pp. 563577). Hillsdale, NJ: Lawrence Erlbaum Associates, Inc.h

[125]. Schraw, G. and Dennison, R. (1994). The effect of reader purpose on interest and recall. Journal of Reading, 26, 1-17.

[126]. Scharlach, T. D. (2008). Start Comprehending: Students And Teachers Actively Reading Text. The Reading Teacher, 62(1), $20-31$.

[127]. Schunk and Zimmerman (2007) Influencing Children's Self-Efficacy And Self-Regulation Of Reading And Writing Through Modeling. Reading \& Writing Quarterly, 23: 7-25.

[128]. Schunk,D. (2008). Metacognition, Self-regulation and Self-regulated Learning : Research recommendations. Educational Psychology Review , 20(4), 463-467.

[129]. Seif El-Deen,A. (2003). Improving EFL College Students Writing Skills Through Interactive Graphic Organizers into the Writing Workshop. Journal of Reading and Literacy (EARL), No. 20,pp. 213-247.

[130]. Simpson, M. and Nist, S. (2000). An update on strategic learning: It's more than textbook reading strategies. Journal of Adolescent and Adult Literacy, 43(6), 528-541.

[131]. Shawaker, P. and Dembo, M. (1996). The Effects of Efficacy-Building Instruction on the Use of Learning Strategies.ERIC Document No. ED 395301.

[132]. Spires, H., Gallini, J. and Riggsbee, J. (1993). Effects of schema-based and text-structure-based cues on expository prose comprehension in fourth graders. Journal of Experimental Education, 60(4), 307-320.

[133]. Swalander,L. \& Taube,K. (2007). Influences of Family Based , Reading Attitude, and Self Regulation on Reading Ability. (ERIC Document Reproduction Service No. (EJ757297).

[134]. Saddler,B. (2006). Increasing Story-Writing Ability Through Self-Regulated Strategy Development: Effects On Young Writers With Learning Disabilities . Learning Disability Quarterly.29, 291-305.

[135]. Sinclair,L. (2004). Principles of Effectice Practice in Supporting Students to become Self -Regulated Learners. Paper presented at NZARE conference,Turning the Kaleidoscope, Wellington, New Zealand

[136]. Singer, B. D., \& Bashir, A.S. (1999). What Are Executive Functions And Self-Regulation And What Do They Have To Do With Language-Learning Disorders? Language, Speech, And Having Services In Schools, 30, 265-273

[137]. Souvignier,E.\& Mokhlesgerami ,J. (2006) Using Self regulation as a Framework for Implementing Strategy Instruction to Foster Reading Comprehension. Learning and Instruction, Vol. 16(1), (ERIC Document Reproduction Service No. (EJ732144). 
[138]. Stetter ,M., E. \& Hughes, M. T. (2010). Using Story Grammar to Assist Students with Learning Disabilities and Reading Difficulties Improve their Comprehension.Education And Treatment Of Children, 33(1),115-151.

[139]. Swalander,L. \& Taube, K. (2007). InXuences of family based prerequisites, reading attitude, and self-regulation on reading ability .Contemporary Educational Psychology, 32, 206-230.

[140]. Tracy,B. Graham ,S.\& Reidgraham R. (2009). Teaching Young Students Strategies for Planning and Drafting Stories: The Impact of Self-Regulated Strategy Development. The Journal of Educational Research.102(5), 323-332.

[141]. Turingan , J. P. (2009).A Cross-Cultural Comparison of Self-Regulated Learning Skills between Korean and Filipino College Students. Asian Social Science,5(12),3-10.

[142]. Urquhart, A. and Weir, C. (1998). Reading in a Second Language: Process, Product and Practice London: Longman.

[143]. Vandrick,S. (2003). Literature In The Teaching Of Second Language Composition. In Barbara,K.(Ed). Exploring The Dynamics Of Second Language Writing. Cambridge, Cambridge University Press.

[144]. Whiteway, R. (1995). A study of the interrelationships among fifth- grade students' concepts of personal relationships, peer relationships, reader self, gender, reading attitude and comprehension. DAI-A, 34(4), 1345.

[145]. Wong, B. Y. L., Harris, K. R., Graham, S. \& Butler, D. L. (2003). Cognitive strategies instruction research in learning disabilities. In H. L. Swanson, K. R. Harris,\& S. Graham (Eds.), Handbook of learning disabilities (pp. 383-402). New York:Guilford Press.

[146]. Yang,Y. (2006). Effects Of Embedded Strategies On Promoting The Use Of Self-Regulated Learning Strategies In An Online Learning Environment . Journal Of Educational Technology Systems ,34, (3 ), 257 - 269.

[147]. Zimmerman, B. J., \& Kitsantas, A. (1999). Acquiring Writing Revision Skill: Shifting From Process To Outcome Self-Regulatory Goals. Journal Of Educational Psychology, 91, 241-250.

[148]. Zimmerman, B. J., \& Kitsantas, A. (2002). Acquiring writing revision and self-regulatory skill through observation and emulation. Journal of Educational Psychology. 94, 660-668.

[149]. Zimmerman, B.J. (1989). A social cognitive view of self-regulated academic learning. Journal of Educational Psychology, 81, 329339.

[150]. Zimmerman, B. J. (1998). Academic Studying And The Development Of Personal Skill: A Self-Regulatory Perspective. Educational Psychologist, 33, 73-86.

[151]. Zimmerman, B. J. (2000). Attaining self-regulation: A social cognitive perspective. In M. Boekaerts, P. R. Pintrich, \& M. Zeidner (Eds.),Handbook of self-regulation (pp. 13-39). New York: Academic Press.

[152]. 122. Zimmerman, B. J. (2002). Self-Regulation, Achieving Self-Regulation: The Trial And Triumph Of Adolescence. In F. Frank Pajares \& T. Urdan (Eds.), Academic motivation of adolescents (pp. 1-28). Connecticut: Information Age Publishing. I

123. Zito J.R., Adkins ,MGavins,M. Harris, K. R. .\& Graham,S. (2007 ). Self-Regulated Strategy Development: Relationship To The Social-Cognitive Perspective And The Development Of Self-Regulation. Reading \& Writing Quarterly, 23: 77-95, 